\title{
Implementasi Pembelajaran Sejarah di Homeschooling pada Program Distance Learning (Studi Kasus di Homeschooling Kak SetoTangerang Selatan 2015)
}

\author{
Oleh : Fitriani \\ Pendidikan Sejarah PPS UNJ
}

\begin{abstract}
This research was conducted with the aim of knowing the history of learning implementations in class 12 SMA in homeschooling kak Seto who followed distance learning programs. The object of this study is the class of 12 high school student inhomeschooling Kak Seto, which follows the learning program distance learning or distance learning independently at home. This study uses a case study.

The research data obtained from the results of observation, interviews and documents related to the matter or object of research. Results from this study showed that children who choose homeschooling distance learning program perform assisted with the teacing of history most of the internet., accompanied by tutors or parent to complete the task of material portofolio, but the result of the evaluation conduced by the tutor/ teacher management homeschooling kak seto child program the average distance learning obtain satisfactory velue.
\end{abstract}

Keyword: Learning, Homeschooling, Distance Learning.

\begin{abstract}
Abstrak
Penelitian ini dilakukan dengan tujuan mengetahui implementasi pembelajaran Sejarah pada siswa kelas 12 SMA di homeshcooling Kak Seto yang mengikuti program distance learning (pembelajaran jarak jauh). Objek penelitian ini adalah siswa kelas 12 SMA di homeschooling Kak Seto (di Tangerang Selatan) yang mengikuti Program pembelajaran distance learning atau pembelajaran jarak jauh secara mandiri dirumah. Penelitian ini menggunakan metode penelitian studi kasus.

Data penelitian ini diperoleh dari hasil observasi, wawancara langsung dan dokumen-dokumen yang terkait dengan masalah atau obyek penelitian. Hasil dari penelitian ini menunjukan bahwa siswa distance learning melakukan pembelajaran sejarah kebanyakan dibantu dengan internet dari pada didampingi oleh tutor untuk menyelesaikan tugas materi portofolionya dan dari hasil evaluasi yang dilakukan oleh tutor/ guru menunjukkan nilai yang baik, namun pada pelaksanaanya materi pembelajaran sejarah banyak tidak diberikan oleh tutor kepada anak distance learning karena kebanyakan dari anak distance lerning menyelesaikan tugas portofolinya dibantu dengan membuka internet. Peranan orangtua dan tutor sangat penting untuk mengawal pembelajaran distance learning yang ideal di homeschooling kak seto.
\end{abstract}

Kata Kunci: Implementasi, Pembelajaran, Perencanaan, Pelaksanaan, Evaluasi, Homeschooler, Homeschooling, Distance Learning.

\section{PENDAHULUAN}

Pendidikan adalah usaha sadar dan terencana untuk mewujudkan suasana belajar dan proses pembelajaran yang membuat anak secara aktif mengembangkan potensi dirinya. Upaya tersebut bertujuan menjadikan anak memiliki kecerdasan spiritual, kecerdasan emosional, dan kecerdasan intelektual, serta keterampilan yang diperlukan dirinya, masyarakat, bangsa dan Negara. 
Dalam undang-undang RI Nomor 20 Tahun 2003 mengamanatkan bahwa pendidikan dapat diselenggarakan secara merata dan berkeadilan. Hak memperoleh pendidikan yang layak bagi seorang anak tidak dibedakan. Pendidikan diselenggarakan berdasarkan dengan menjunjung tinggi hak azazi manusia, nilai keagamaan, nilai budaya dan nilai keberagaman/kemajemukan bangsa.

Siswa dalam Undang-Undang No.20 Tahun 2003 tentang Sistem Pendidikan Nasional (Sisdiknas) adalah anggota masyarakat yang berusaha mengembangkan potensi diri melalui proses pembelajaran yang tersedia pada jalur, jenjang dan jenis pendidikan tertentu, dengan tujuan meningkatkan kompetensi siswa. Kompetensi siswa merupakan sebuah kemampuan yang harus dimiliki siswa setelah mengikuti pembelajaran. Kemampuan tersebut adalah hasil dari perpaduan pengetahuan, keterampilan, nilai, dan sikap yang direfleksikan dalam aspek kognitif, afektif dan psikomotorik. Untuk dapat mengembangkan ketiga ranah tersebut pada siswa maka memerlukan campur tangan sekolah sebagai sebuah lembaga pendidikan.

Sekolah atau lembaga pendidikan manapun berkewajiban untuk mengakomodir semua anak dalam memperoleh haknya untuk memperoleh pendidikan yang sesuai dengan kebutuhan anak. Sekolah sebagai lembaga penyelenggara pendidikan harus dapat memberikan layanan pendidikan yang sesuai dengan kebutuhan anak. Sehingga kebutuhan anak dalam memperoleh pendidikanya dapat terpenuhi tanpa prilaku diskriminatif. Karena pada hakikatnya seorang anak adalah unik.

Untuk itu dirasakan perlunya peyelenggaran pendidikan yang memperhatikan kebutuhan anak berdasarkan pada kenyataan bahwa anak pada hakekatnya unik atau memiliki perbedaan kebutuhan serta memiliki kemampuannya yang berbeda. Pada kenyataanya, ada sebagian anak tidak ingin bersekolah di sekolah formal karena masalah tertentu, seperti kasus bullying, bahkan pemasungan kreatifitas anak, baik yang secara disengaja atau tidak yang dilakukan oleh oknum guru, lembaga atau orang tua.

Pengalaman-pengalaman yang tidak menyenangkan tersebut menjadi penyebab buruknya kondisi belajar anak, belajar anak kurang kondusif dan menimbulkan ketidaknyamanan terhadap sekolah/ lembaga penyelenggara pendidikan. Ketidaknyamanan itu memicu keputusan orang tua untuk mengeluarkan anaknhya dari sekolah formal dan memilih sekolah alternatif seperti homeschooling.

Keputusan orang tua dalam memilih homeschooling sebagai sekolah anaknya, dianggap bisa menjadi solusi untuk mengendalikan dan mengawasi serta memberikan fokus yang penuh terhadap kondisi belajar anak. Orang tua dibantu bersama dengan penyelenggara homeschooling mempunyai kekuatan secara penuh untuk mengendalikan dan mengawasi sistem pembelajaran di homeschooling.

Ketika mengikuti homeschooling anak-anak diharapkan mendapatkan perhatian yang lebih dari orang tua maupun tutornya (sebutan untuk guru di homeschooling). Maka bentuk pembelajarannya dapat dirancang senyaman mungkin, dikondisikan sesuai dengan kebutuhan anak, kemampuan belajar anak dan minat serta bakat anak.

Namun pada kenyataanya homeschooling 
memiliki kelebihan dan kekurangannya sebagai pendidikan alternatif. Kelebihannya, antara lain: homeschooling sebagai lembaga pendidikan alternatif mampu membuat desain pembelajaran yang fleksibel untuk menciptakan kondisi belajar yang sesuai dengan kebutuhan anak dan orang tua.

Desain pembelajaran yang fleksibel, dinamis, tidak kaku, tidak terstruktur, tidak dan tidak terikat menyesuaikan kapan anak harus memulai pembelajaranya. Fleksibel artinya baik materi maupun jam belajar pada anak dapat dirubah sesuai kebutuhan anak atas kesepakatan dengan orang tua dan tutor. Adapun dimana homeschooling diselenggarakan juga bersifat dinamis, pembelajaran di homeschooling tidak hanya diselenggarakan di dalam rumah saja, tapi juga bisa diselenggarakan di mall, museum, café, atau area umum lainya baik indoor atau autdoor. Penyesuaian dimana pembelajaran homeschooling dapat diselenggarakan dibuat atas kebutuhan dan kesepakatan bersama antara anak, orang tua dan tutor.

Kelebihan lainnya, dari sistem pembelajaran di homeschooling adalah, Orang tua mempunyai banyak waktu untuk memperhatikan anak- anak mereka dirumah. Selain dari pada itu, baik orang tua atau anak berhak mendesain waktu, tempat dan materi pembelajaran sesuai dengan kehendak bersama antara anak dan orang tua, tentunya sejalan dengan visi dan misi dari penyenggara homeschooling. Hal-hal tersebut tadi dapat menciptakan kondisi belajar yang nyaman dan kondusif bagi anak.

Disamping

kelebihannya, homeschooling juga banyak memiliki kekurangan, antara lain: homeschooling belum tentu dapat membuat anak rajin dan terarah dalam kegiatan belajar dan pembelajaran yang diselenggarakan di rumah atau diluar rumah. Sangat mungkin dalam homeschooling anak dan orang tua akan sulit dikendalikan untuk mengikuti pembelajaran yang disesuaikan dengan target dan waktu yang telah disusun oleh penyelenggara homeschooling. Belum lagi jika anak dan orang tua hidup tidak teratur dan tidak disiplin. Maka hal tersebut akan jauh dari yang disebut homeschooling ideal seperti yang diinginkan oleh peyelenggara. Permasalahan itu akan menjadi salah satu alasan timbulnya masalah- masalah pada tahap evaluasi belajar anak nanti.

Dalam evaluasi belajar anak, anak dituntut untuk menyelesaikan soal-soal tes LK (lembar kerja), modul (muatan materi yang didesain oleh tim internal) penyelenggara homeschooling, soal uts dan soal uas yang dibuat dengan merujuk pada materi modul. Tahapan evaluasi dengan menggunakan semua tes tersebut sesuai dengan jadwal penyelenggaraan homeschooling layaknya seperti sekolah formal. Jadwal peyelenggaraan homeschooling disebut jadwal akademik, dimana jadwal akademik dibuat oleh peyelenggara homeschooling dengan target waktu dan pencapaian tertentu. Jadwal tersebut dibuat dengan perencanaan pembelajaran yang didasari pada kurikulum ktsp (kurikulum tingkat satuan pendidikan). Maka jika tidak tepat waktu, akan menghasilkan banyak masalah pada proses belajarnya, seperti anak menjadi malas, tidak disiplin, tidak bertanggung jawab pada tugas dan kewajibanya sebagai siswa. Lainnya orangtua juga tidak bisa melakukan pengendalian yang baik kepada sikap belajar anak yang kurang baik, karena keterbatasan, seperti sikap tidak konsisten pada anak, tidak mampu memberi sanksi 
dan hukuman yang jelas pada sikap anak yang tidak taat aturan dan kesibukan lain yang dialami orang tua. Hal-hal tersebut tadi akan berjalan tidak sesuai dengan yang direncanakan, dan dampaknya akan terlihat pada sikap dan evaluasi belajar anak baik langsung maupun tidak.

Jika dalam tahap perencanaan dan evaluasi penyelenggaraan homeschooling sedikit banyak sama dengan sekolah formal, namun pada tahap pelaksanaanya atau proses pembelajaranya menganut sistem fleksibilitas. Fleksibelitas dalam proses pelaksanaan pembelajaran tersirat dalam hal standar budaya yang dibuat dan ditentukan oleh peyelenggara homeschooling. Seperti budaya berpakaian, budaya berkomunikasi dengan tutor/guru di homeschooling. Pada tahap pelaksanaanya inilah yang terlihat berbeda antara sekolah formal dan homeschooling.

Fleksibelnya sistem penyelenggaraan homeschooling terlihat pada tahap pelaksanaan pembelajarannya, pendidikan yang didasari pada filosofi belajar "belajar dimana saja, kapan saja dan dengan siapa saja" membuat baik anak maupun orang tua cenderung tidak terarah dan tidak sistematis dalam melaksanakan kegiatan belajar anak secara terencana.

Dalam menentukan perencanaan pembelajaran pihak orang tua dan anak berkonsultasi dan bekerjasama dengan pihak penyelenggara homeschooling untuk mengidentifikasi, menganalisis dan memutuskan seorang anak untuk mengikuti perencanaan pembelajaran program komunitas atau distance learning (jarak jauh).

Program komunitas adalah program perencanaan pelaksanaan pembelajaran yang dilaksanakan di dalam ruangan atau gedung sekolah homeschooling dengan beragam fasilitas sarana dan prasarana yang memadai, bersistem dan terdiri dari komponen-komponen serta perangkat pelaksanaan pembelajaran. Program komunitas menempatkan siswa-siswi homeschooling dalam pembagian kelas berdasarkan kelompok latar belakang siswa. Sepenuhnya pembelajaran dikendalikan oleh penyelenggara dan para tutor (sebutan untuk guru dalam homeschooling) secara sistematis.

Berbeda dengan program distance learning atau (pembelajaran jarak jauh), siswa dan orang tua memutuskan secara mandiri untuk menyelenggarakan pembelajaran mandiri dirumah. Dalam pelaksanaan pembelajaranya siswa secara aktif dan mandiri belajar dengan atau tanpa bantuan tutor/guru. Kondisi tersebut diputuskan diawal orang tua dan siswa ketika mendaftar di homeschooling.

Program distance learning sendiri mempunyai banyak kelebihan dan kelemahan. Kelebihanya antara lain: 1, siswa berhak mengembangkan bakat dan minatnya pada suatu hal, 2 . Siswa tidak merasa dibebani oleh model pembelajaran formal (yang kaku, terstruktur dan terencana), 3. Siswa dan orang tua berhak menentukan desain pembelajaranya sendirikapandandimanaharusmelakukan pembelajaran. Sedangkan kekuranganya antara lain: 1, siswa terkadang sulit diarahkan untuk belajar secara mandiri, 2. Orang tua terlalu sibuk, sehingga tidak fokus melaksanakan pembelajaran dengan anak dirumah, 3 . Orang tua tidak mengerti dan tidak mempunyai pengalaman dalam memberikan pengajaran kepada anaknya karena tidak mempunyai background pendidikan.

Dalam program distance learning atau komunitas seorang anak akan 
tetap diharuskan untuk mencapai penyelesaian materi yang telah di desain oleh homeschooling melalui modul pembelajaran yang bersifat reduktif jika dibandingkan dengan materi sekolah formal. Hal tersebut dianggap perlu dilakukan untuk menekan tingginya beban tugas dan pemahaman materi pada anak. Karena hal tersebut akan membuat anak tidak ingin belajar dan trauma pada sekolah seperti di sekolah formal kembali berulang. Karna tujuan yang paling penting dari homeschooling adalah mengembangkan minat dan bakat anak, jadi tidak serta merta hanya terfokus pada prestasi belajar anak dalam ranah kognitif saja.

Jadi muatan materi yang didesain dalam modul yang sederhana itu, tetap berdasarkan kurikulum KTSP (Kurikulum Tingkat Satuan Pendidikan) yang dianggap sebagai kurikulum yang dapat mengembangkan karakter anak. Untuk desain materi modul mungkin sama dengan sekolah formal yang mamuat beberapa mata pelajaran. Pada homeschooling mata pelajaran dibagi menjadi 3 kelompok, kelompok A, Kelompok B dan Kelompok C.

Kelompok A terdiri dari (Pendidikan Agama, Pendidikan Kewarganegaraan, Bahasa Indonesia, Bahasa Inggris, Matematika, Ekonomi, Geografi, Sosiologi dan Sejarah. Kelompok B terdiri dari (seni budaya, pendidikan jasmani dan kesehatan dan teknologi Informatika dan Komunikasi). Sedangkan kelompok C terdiri dari (Friday Class, Project Class: Enterpreuner, Study Refresh, Outing, DL Gathering dan Talent Class: Futsal).

Terlihat bahwa Sejarah masuk dalam mata pelajaran kelompok A, yang dianggap penting, namun pada implementasinya pelajaran sejarah hanya dicover dalam sebuah portofolio bulanan yang dikerjakan oleh siswa distance learning secara mandiri dengan atau tanpa pembahasan materi dari tutor/guru homeschooling.

Terlihat bahwa ada kesenjangan antara perencanaan, evaluasi dan pelaksanaan (implementasi) pelaksanaan pembelajaran sejarah dalam program distance learning secara mandiri.

\section{Fokus Penelitian}

Seperti yang telah dipaparkan pada bab sebelumnya bahwa penelitian ini mengambil fokus tentang bagaimana implementasi pembelajaran sejarah dalam program distance learning di kelas 12 IPS Homeschooling Kak Seto.

Adapun fokus dari penelitian ini terbagi atas beberapa sub fokus sebagai berikut: (1) Proses pembelajaran sejarah yang diterapkan melalui metode yang di tentukan Homeschooling dalam pembelajaran Sejarah. (2) Peran orang tua dan tutor dalam pembelajaran materi sejarah. (3) Bagaimana latarbelakang dan alasan siswa dan orang tua memilih Program Distance Learning di Homeschooling Kak Seto.

\section{Rumusan Masalah}

Berdasarkan latar belakang masalah yang telah dijelaskan sebelumnya, maka rumusan masalah dalam penelitian ini disebutkan sebagai berikut:

1. Bagaimana proses pembelajaran sejarah dalam program distance learning di homeschooling kak seto?

2. Bagaimana peran orang tua dan tutor dalam pembelajaran materi sejarah tersebut?

3. Bagaimana latar belakang dan alasan 
siswa dan orang tua memilih program Distance Learning di homeschooling Kak Seto?

\section{Kegunaan Penelitian}

Hasil penelitian ini diharapkan dapat memberikan manfaat bagi banyak pihak, setidaknya bagi dunia pendidikan umumnya. Bagi tutor, dari penelitian yang dilaksanakan, akan diperoleh pengetahuan yang lebih mendalam mengenai pendidikan informal guna mendalami pemahaman karakter, minat dan bakat anak. Disamping itu juga tutor akan dapat mengetahui strategi pembelajaran yang baik dan akomodatif dalam proses pembelajaran sejarah di dalam pendidikan informal.

Bagi peneliti lain, hasil ini diharapkan dapat dipakai untuk memperluas wawasan informasi empirik dan dapat dijadikan rujukan untuk melakukan penelitian lanjutan di bidang studi yang lain.

Bagi pemerintah atau instansi terkait, dalam hal ini Kementerian Pendidikan dan Kebudayaan, hasil penelitian dapat dipakai sebagai masukan agar proses pembelajaran sejarah di sekolah informal berjalan secara efektif dan efisien.

Bagi pemerhati, peminat dan pecinta dunia pendidikan, khususnya pendidikan sejarah, penelitian ini diharapkan dapat bermanfaat sebagai sarana untuk meningkatkan pengetahuan tentang pembelajaran sejarah di sekolah informal, serta strategi yang cocok digunakan, kendala-kendala dalam penyelenggaraan pembelajaran sejarah di sekolah informal dan tindakan-tindakan serta penanggulangan yang dapat dilakukan. Selain itu, hasil penelitian ini juga memiliki keguanaan baik secara teoritis maupun secara praktis.

\section{TINJAUAN TEORITIS}

A. Deskripsi Konseptual Fokus dan Subfokus

1. Distance Learning Homeschooling

a. Sejarah Distance Learning Homeschooling

Jika kita menilik sejarah literature gerakan distance Learning homeschooling di Amerika Serikat, kita tak akan bisa lepas dari buku How Cildren Fail (1964) karya John Holt. Buku yang sampai kini telah terjual jutaan kopi itu bereputasi sebagai karya klasik di bidang pendidikan. Dalam bukunya Holt menulis tentang berbagai trik siswa-siswi di sekolahnya agar guru mengira mereka telah paham pelajaran. Di buku itu Holt menulis bahwa kegagalan akademis seseorang anak bukan disebabkan oleh aktivitas pembelajaran di sekolah akan tetapi karena sekolah itu sendiri.

Banyak dari keluarga di Amerika saat itu yang berespon positif pemikiran Holt. Orang tua benar-benar mendidik anakanaknya di rumah (distance learning). Dalam proses pelaksanaanya para orang tua itu berkorespondensi dengan Holt. Hingga akhirnya di tahun 1977, Holt menerbitkan majalah yang banyak berisi informasi-informasi mengenai pelaksanaan distance learning pada homeschooling.

Holt pernah menulis, " I want to make it clear that I don't see home schooling as some kind of answer to badness of schools. I think that the home is the proper base for the exploration of the world which we call learning or education home would be the best base no matter how good the schools were" (saya perjelas bahwa Homeschooling bukan jawaban atas jeleknya kualitas sekolah. Saya kira 
rumah adalah tempat yang tepat untuk Pengertian Homeschooling dan Distance Learning

Homeschooling adalah istilah yang relatif baru dalam dunia pendidikan di Indonesia. Homeschooling adalah school at home, home education, home-based, dan sebagainya, dengan menggunakan rumah sebagai basis pembelajaran (distance learning). Dalam bahasa Indonesia, istilah ini diperkenalkan oleh Kementrian Pendidikan dan Kebudayaan adalah sekolah rumah. Istilah ini juga digunakan oleh asosiasi yang bernama ASAH PENA (Asosiasi Sekolah Rumah dan Pendidikan Alternatif Indonesia). Dalam bahasa umum homeschooling adalah model belajar yang digunakan oleh orang dewasa untuk mendapatkan informasi atau keterampilan sesuai dengan kebutuhanya.

Istilah homeschooling atau sekolah rumah bukan keluar sebagai sekolah alternatif yang menjadi lawan dari bentuk sekolah formal, namun di harapkan dapat menjadi wadah untuk memenuhi hak-hak anak dalam pendidikan. Banyak publikasi dan pemberitaan mengenai homeschooling, banyak pertanyaan dan keingintahuan mengenai homeschooling.

Homeschooling adalah sebuah sistem pendidikan atau pembelajaran yang diselenggarakan di rumah dan jauh dari penyelenggara pendidikan/sekolah (distance learning). Homeschooling merupakan sekolah alternatif yang menempatkan anak-anak sebagai subyek dengan pendekatan secara "at home" atau di rumah. Melalui pendidikan "at home" inilah anak-anak merasa nyaman belajar karena mereka dapat belajar apapun sesuai dengan keinginanya, kapan saja, di mana saja, dan dengan siapa saja, seperti ia tengah belajar di rumahnya. Jadi, meski disebut homeschooling, tidak berarti anak akan terus menerus belajar di rumah, tapi anak-anak dapat belajar di mana saja kapan saja asal situasi dan kondisinya benar-benar nyaman dan menyenangkan seperti "at home". Maka dalam sistem homeschooling, jam pelajaran bersifat fleksibel. Mulai dari bangun tidur sampai berangkat tidur kembali.

Pengertian Distance learning sangatlah beragam menurut para ahli. Moore mengatakan keterlibatan media Internet dalam Distance Learning memberikan kesempatan bagi anak untuk berkomunikasi dan berdialog atau berinteraksi dengan tutor/guru relatif lebih besar. Hal ini dengan mengunakan beragam fasilitas internet, juga adanya dukungan tool-tool pendukung seperti web cam, head phone, dan lain-lain.

\section{b. Legalitas Homeschooling}

Sedangkan soal legalitas dari homeschooling sendiri,mengacu pada Undang-undang No. 20 Tahun 2003 tentang sistem pendidikan Nasional mengakomodasi homeschooling sebagai salah satu alternatif pembelajaran yang dapat dilakukan oleh masyarakat. Dalam pelaksanaanya homeschooling berada di bawah naungan Direktorat Pendidikan Kesetaraan, Direktorat Jenderal Pendidikan Luar Sekolah, Departemen Pendidikan Nasional. Siswa yang memilih homeschooling akan memperoleh izajah kesetaraan yang di keluarkan oleh Depdiknas yaitu paket A setara SD, paket B setara SMP dan paket C setara SMU. Ijazah ini dapat digunakan, untuk meneruskan pendidikan ke sekolah formal atau yang lebih tinggi bahkan ke luar negeri sekalipun. 


\section{Sejarah dan Pembelajaran Sejarah}

a. Pengertian Sejarah

Istilah "sejarah" yang dikenal selama iniberasal dari bahasa arab "syajaroh" yang berarti pohon. Istilah syajaroh ini sering dikaitkan dengan istilah silsilah. Kata syajaroh masuk ke Indonesia setelah terjadi akulturasi anatara kebudayaan Indonesia dengan kebudayaan Islam. Pengertian syajarah sama dengan apa yang kini di Indonesia disebut silsilah, yakni daftar asal-usul atau daftar keturunan. Silsilah kalau kita gambarkan secara skematis, akan tampak seperti pohon dengan cabang dan rantingnya menurut Nugroho. Hal ini sebagaimana diungkapkan Kartodirdjo bahwa sejarah sebagai silsilah, asal-usul (keturunan), kejadian, dan peristiwa yang benar-benar terjadi pada masa lampau. Kejadian dan peristiwa yang benarbenar terjadi itu berupa aktifitas yang berhubungan dengan kejadian-kejadian tertentu, kemudian disusun oleh seorang sejarawan.Selain itu, pengertian sejarah mengandung suatu konsep, yaitu sejarah sebagai suatu ilmu dan seni.

b. Pengertian Belajar dan Pembelajaran

Belajar sering dikaitkan dengan segala aktivitas manusia yang menimbulkan perubahan relatif menetap, baik dalam bidang pengetahuan, keterampilan, maupun sikap. Pengertian tersebut didukung oleh pernyataan Gradle bahwa belajar adalah perubahan tingkah laku manusia yang dapat diindentifikasikan dengan membandingkan tingkah laku antara sebelum dan sesudah dikondisikan dalam situasi belajar.

Tujuan instuksional pembelajaran sejarah di sekolah menengah atas menurut S. K. Kuchhar adalah, mengembagkan a). pengetahuan, b). pemahaman, c) pemikiran kritis, d). keterampilan praktis, e). minat dan f). perilaku. Sedangkan menurut Sapriya mata pelajaran sejarah bertujuan agar peserta didik memiliki kemapuan.

\section{B. Hasil Penelitian yang Relevan}

Penelitian yang relevan dengan penelitian ini adalah penelitian pada karya Tesis dengan judul " Pengaruh Implementasi Kurikulum Tingkat Satuan Pendidikan (KTSP), Proses Pembelajaran, dan Desain Pembelajaran PAIKEM Terhadap Kompetensi Siswa (Studi Empiris pada Komunitas Homeschooling di Tangerang Selatan) yang ditulis oleh Dimas Ramdhani Triputra pada tahun 2014. Penelitian dengan tujuan untuk mengetahui pengaruh implementasi Kurikulum KTSP, Proses Pembelajaran, dan desain pembelajaran PAIKEM terhadap kompetensi siswa baik secara parsial maupun simultan. Penelitian ini menggunakan teknik analisis model regresi linier sederhana dan berganda dengan data primer yang diperol dari jawaban 51 responden dari Homeschooling Kak Seto, Homeschooling Technosa, Homeschooling Pelangi dan Homeschooling Primagama.

Berdasarkan hasil uji $t$ dan uji $f$ penelitian ini menunjukkan bahwa $\mathrm{H} 0$ ditolak dan Ha di tara parsial maupun simultan pada variabel implementasi KTSP, proses pembelajaran, dan desain pembelajaran PAIKEM.

\section{METODOLOGI PENELITIAN}

\section{A. Tujuan Penelitian}

Penelitian ini bertujuan untuk mendeskripsikan dan mengungkapkan proses pembelajaran sejarah dalam pendidikan informal melalui program distance learning) di homeschooling Kak Seto. Pada prinsipnya, peneliti akan meneliti bagaimana proses pembelajaran 
sejarah yang diberikan oleh orang tua dan tutor di sekolah homeschooling Kak Seto melalui program distance learning.

\section{B. Tempat dan Waktu Penelitian}

Penelitian ini dilaksanakan di homeschooling kak seto Jakarta.Alasan pengambilan lokasi tersebut adalah karena homeschooling kak seto adalah model sekolah alternatif informal yang sudah cukup lama menjadi sekolah berskala nasional, sekolah alternatif yang mengakomodir siswa-siswa yang memiliki latar belakang masalah di sekolah formal dan lainya.

Sebelum peneliti menentukan topik penelitian, peneliti telah melakukan studi pra lapangan atau proses grand tour observation. Atau studi awal untuk mencari sisi atau hal-hal unik yang terjadi dalam fokus masalah.Adapun, rencana waktu penelitian ini dilaksanakan pada bulan Maret 2015-Juni 2015, waktu penelitian ini dapat berubah berdasarkan data yang didapatkan di lapangan.

\section{Latar Penelitian}

Latarpenelitianadalahhomeschooling kak seto Jakarta. Sedangkan obyek yang akan diteliti dalam penbelitian ini adalah, kelas 12 IPS SMA dalam program Destance Learning di HSKS.

D. Metode dan Prosedur Penelitian

Penelitian ini menggunakan pendekatan kualitatif, penelitian dengan pendekatan kualitatif adalah metode penelitian yang digunakan untuk meneliti pada kondisi obyek yang alamiah sebagai lawanya adalah eksperimen dimana peneliti adalah sebagai instrument kunci, teknik penggumpulan data digunakan secara triangulasi (gabungan), analisis data bersifat induktif dan hasil penelitian kualitatif lebih menekankan makna daripada generalisasi. Menurut Moleong ciri-ciri penelitian kualitatif adalah : 1 . Latar alamiah, 2. Manusia sebagai alat atau instrument, 3. Analisis data secara induktif, 4. Teori dari dasar, 5. Deskriptif. Penelitian ini dilakukan dengan menggunakan metode penelitian kualitatif dengan menggunakan metode studi kasus.

Studi kasus adalah salah satu metode penelitian ilmu-ilmu sosial yang merupakan strategi yang lebih cocok bila pokok pertanyaan suatu penelitian berkenaan dengan how dan why, bila peneliti hanya memiliki sedikit peluang untuk mengontrol peristiwa-peristiwa yang akan diselidiki, dan bilamana fokus penelitiannya terletak pada fenomena kontemporer masa kini di dalam konteks kehidupan nyata.

Penelitian studi kasus, biasanya metode pengumpulan datanya adalah: (a) metode observasi partisipatif, sehingga peneliti harus membuat pedoman observasi dengan merinci aspe-aspek yang akan diobservasi: dan (b) metode wawancara tak berstruktur yang akan dilakukakan pada responden.

$\mathrm{P}$ eneliti dalam hal ini menggunakan langkah-langkah penelitian dari Robert $\mathrm{K}$ Yin, yang dalam penelitian kualitatif menjabarkan langkah-langkahnya yang terdiri atas penggumpulan data, membuat desain penelitian, mereduksi data, menganalisis data dan memvalisasinya serta membuat kesimpulan dari hasil penelitian.

Berikut ini akan peneliti kemukakan langkah-langkah penelitian yang digunakan:

1. Pengumpulan Data. Pada tahap ini, peneliti melakukan proses grand tour observational studi awal secara langsung. Peneliti melakukan studi awal untuk 
mencari keunikan yang ada di sekolah Homeschooling Kak Seto Jakarta. Selain itu yang menjadi studi awal untuk memetakan masalah atau menemukan serta memunculkan fokus dari penelitian yang akan dilakukan.

2. Membuat Desain Penelitian. Setelah peneliti menemukan bukti-bukti yang ada di sekolah Homeschooling Kak Seto, tahap selanjutnya peneliti membuat desain penelitian.dalam tahap ini, peneliti menggabungkan data yang terkempul, kemudian menggabungkan dengan konsep yang berkaitan dengan penemuan data yang ada di lapangan. Pada tahap ini juga peneliti, membuat protocol riset, baik merupakan pedoman observasi atau merupakan pedoman wawancara. Kedua pedoman ini digunakan untuk membantu peneliti dalam menggali data lebih dalam lagi saat melakukan observasi maupun wawancara dengan key informan atau pemegang informan kunci.

3. Mereduksi Data. Pada tahapan ini, data yang terkumpul secar untuk tidak langsung peneliti sudah reduksi kedalam masing-masing sub fokus untuk diteliti lebih lanjut. Reduksi data diperlukan untuk melihat secara lebih jelas kelompok data mana saja yang memerlukan data tambahan untuk menghasilkan temuan yang lebih akurat selain juga memerlukan peneliti dalam membuat koding atau kode untuk mengelompokkan hasil wawancara dan hasil pengamatan.

4. Menganalisis dan Validasi Data. Tahapan ini penting untuk dilakukan karena setelah peneliti menggunakan reduksi data dan mengelompokkan datadata tersebut menggunakan kode-kode, maka data tersebut harus dianalisa. Dalam hal ini, peneliti membandingkan temuan di lapangan dengan konsep yang peneliti pakai. Proses membandingkan tersebut akan mengarah kepada sebuah tahapan yang disebut validasi data. Validasi data terjadi, jika semua partisipan yang terlibat dalam penelitian memberikan jawaban atau pemahamaan yang sama dengan key informan atau informan kunci serta konsep yang digunakan.

5. Membagi Hasil Temuan. Tahapan akhir ini diperlukan untuk memberikan gambaran jelas tentang hasil pengolahan data di lapangan. Dalam hal ini, peneliti mengungkapkan berbagai hasill temuan dilapangan selama penelitian ini berlangsung. Hasil temuan akan membantu peneliti untuk membuat rekomendasi atau member saran kepada sekolah Homeschooling Kak Seto, Jakarta mengenaii hal-hal apa saja yang bersifat konstruktif untuk membangun dan mengembangkan sekolah Homeschooling sebagai salah-satu perwujudan dari pendidikan alternatif bagi siswa yang memiliki latar belakang berbeda dan tidak bisa bersekolah di sekolah formal.

\section{E. Data dan Sumber Data}

Data dari penelitian ini sebagian besar adalah berupa catatan hasilnya langsung yang penelitilakukan pada awal penelitian, berdasarkan studi awal yang dilaksanakan pada saat Grand Tour Observation, peneliti telah sampai pada kesimpulan bahwa sekolah Homeschooling Kak Seto Jakarta merupakan sebuah sekolah alternative yang pada pelaksanaanya menerima siswa-siswi dengan latar belakang dan masalah yang dibawanya baik dari sekolah formal sebelumnya atau latarbelakang permasalahan yang mendasari homescooler memilih homeschooling.

Peneliti juga harus memutuskan bagaimana akan melakukan penyimpanan data sehingga dapat dengan mudah 
menemukan data yang telah terkumpul dan dilindungi dari kemungkinan rusak atau hilang.

Tahap berikutnya dari langkahlangkah untuk mendesain penelitian ini mengarah pada pilihan keempat yaitu mengenai sampling. Dalam tahap ini maka peneliti akan dihadapkan pada masalah yang berkaitan dengan responden (sampling) dari unit khusus, serta jumlah dari responden yang akan dimasukkan dalam penelitian ini. Tantangan yang muncul dari pengambilan sampel yang mempertimbangkan pada kekhususan ketika sampel diambil dalam kajian penelitian ini.

Dalam penelitian kualitatif, sampel yang mungkin dipilih secara sengaja dikenal dengan nama poroposive sampling. Tujuan utama dari pemilihan kajian didalam penelitian yang menggunakan metode kualitatif ini adalah iuntuk memiliki orang-orang yang akan menghasilkan data yang paling relevan dan berlimpah.

Adapun metode pengumpulan data yang digunakan dalam penelitian ini adalah: wawancara, observasi dan kuesioner serta dokumentasi. Dalam penelitian ini, peneliti membagi data menjadi dua kelompok, yaitu data primer dan sekunder.

Data primer berupa key informan atau informan kunci, penentuan informan dalam penelitian ini adalah secara purposive sampling atau sampel bertujuan dan snowball sampling, yakni meminta informan untuk menunjuk orang lain yang dapat memberikan informasi. Pemilihan key informan atau informan kunci berdasarkan keterlibatanya dalam penyelenggaraan sekolah homeschooling kak seto dan kertelibatanya dalam proses pembelajaran Sejarah di homeschooling kak seto.

Kelompok data kedua yaitu data sekunder berupa bentuk-bentuk keragaman yang ada di sekolah Homeschooling Kak Seto, yang peneliti gambarkan dalam bentuk chart prosentase, kolase fhoto berisi berbagai kegiatan rutin, event kegiatan sekolah, catatan lapangan berupa hasil pengamatan secara general maupun harian serta video berupa rekaman wawancara dan pengamatan peneliti akan topik penelitian.

F. Teknik dan Prosedur Pengumpulan Data

Dalam penelitian kualitatif, data yang relevan berasal dari empat bidang kegiatan yang berbasis pada: wawancara (interview), pengamatan observasi,mengumpulkan dan memeriksa bahan atau materi study dokumentasi, dan perasaan dapat melalui audiovisual. Dalam melaksanakan interview wawancara, kontras anatara wawancara terstruktur dan kualitatif menarik perhatian khusus dimana terdapat riset protokol dalam pelaksanaanya sehingga peneliti dalam melakukan pengamatan, wawancara dan pelitian menjadi tidak bias. Sedangkan dalam pengamatan atau observasi pentinguntuk melibatkan ketentuan akan hal-hal yang berkaitan dengan "apa", "kapan", dan "dinama" untuk mengamati. Hal ini tercermin dalam resit protokol yang telah dibuat sebelumnya. Sedangkan pada fase pengumpulan materi, banyak tipe yang berbeda dari objek dapat bermanfaat dan terkumpul ketika melaksanakan penelitian lapangan, lalu perasaan, dapat diwakili oleh beberapa indera peraba dimana melibatkan suara, kecepatan temporal, dan kehangatan atau dinginya pengaturan lapangan serta dugaan tentang hubungan 
sosial di antara peserta.

Dalam penelitian ini perlu kiranya motif untuk berbagi pekerjaan dengan responden berupa hubungan baik dengan koreksi dan perubahan yang akan meningkatkan keabsahan penelitian dan hubungan untuk mendukung kolaboratif dan etis dengan responden, pada tahap ini peneliti akan menjelaskan tentang metode pengumpulan datanya. Dalam studi kasus, biasanya metode pengumpulan datanya adalah: a). metode observasi partisipatif, sehingga peneliti harus membuat pedoman observasi dengan memperinci aspek-aspek yang perlu di observasi. b). metode wawancara terstruktur, bahwa dalam hal ini peneliti juga menyusun pedoman wawancara yang akan dilakukan pada responden.

Untuk mengumpulkan data pada penelitian ini, maka penelitian mengembangkan riset protokol atau suatu bentuk panduan pertanyaan tertulis untuk perekaman informasi dan juga kebutuhan untuk mengembangkan beberapa bentuk perekaman data lain, misalnya wawancara ataupun protokol observasional. Selain itu, peneliti juga perlu mengantisipasi masalah pengumpulan data, yakni apa yang menjadi "masalah lapangan", yang mungkin nantinya akan menjadi masalah, misalnya saja adanya kepemilikan data yang memadai dilapangan, sehingga perlu untuk meninggalkan lapangan penelitian lebih awal, ataupun memberikan kontribusi terhadap informan yang sebenarnya hilang.

Dalam pengumpulan data pada proses studi kasus ini, maka paling tidak ada lima keterampilan yang harus dimiliki peneliti antara lain:

1) Peneliti harus mampu mengajukan pertanyaan-pertanyaan yang baik, dan menginteprasikan jawaban-jawaban responden.

2) Peneliti harus menjadi pendengar yang baik dan tidak terperangkap kepada ideology atau paham serta prokonsepsinya sendiri.

3) Peneliti harus mampu menyesuaikan dirinya sendiri atau bersikap fkeksibel,agar situasi yang baru bisa dipandang sebagai peluang dan bukan sebagai ancaman.

4) Peneliti harus memiliki daya tangkap yang kuat terhadap isue-isue yang diteliti dan

5) Peneliti tidak bisa penyimpangan terhadap anggapan-anggapan yang sudah ada sebelumnya termasuk anggapan dari teori. Oleh karena itu, peneliti harus peka dan responsive terhadap bukti-bukti yang kontradiktif.

Berdasarkan pengertian tersebut, prosedur pengumpulan data dalam peneliti ini dilakukan dengan beberapa cara berikut:

1. Wawancara. Teknik ini dipakai karena wawancara dapat digunakan oleh peneliti untuk lebih cepat memperoleh informasi yang dibutuhkan, lebih meyakinkan peneliti bahwa responden menafsirkan pertanyaan dengan benar, memberikan kemungkinan besar atau keluwesan dalam proses pengajuan pertanyaan, banyak pengendalian yang dapat dilatih dalam konteks pertanyaan yang diajukan dan jawaban yang diberikan, informan dapat lebih siap diperiksa kesahihanya atasdasar isyarat non verbal.

2. Kuesioner. Selain wawancara, penelitianinijuga menggunakan kuesioner untuk mengumpulkan data penelitian. Kuesioner berisi sejumlah pernyataanpernyataan yang dikembangkan dari kisikisi instrument penelitian, penggunaan kuesioner dilandasi oleh pertimbangan 
bahwa responden adalah benar dan dapat dipercaya, dan intepretasi responden tentang pertanyaan/pernyataan yang diajukan adalah sama dengan apa yang dimaksud peneliti.

3. Observasi. Teknik ini digunakan untuk memperoleh fakta-fakta yang tampak dan memperoleh dimensi-dimensi baru, serta pemahaman konteks maupun fenomena yang teliti.

4. Dokumentasi. Teknik ini digunakan untuk menelusuri data-data dokumentasi di lokasi penelitian yang terkait dengan tema penelitian. Dokumen-dokumen terkait digunakan sebagai pendukung hasil wawancara dan observasi.

Jadi dalam hal ini pengamatan dikombinasikan dengan wawancara kepada pihak-pihak yang dapat mendukung data dan studi dokumen (triangulasi).Triangulasi dilakukan untuk melihat gejala dari berbagai sudut dan melakukan pengujian temuan dengan menggunakan berbagai sumber informasi dan berbagai teknik.

Empat macam triangulasi yang digunakan dalam penelitian ini adalah pemeriksaan dengan memanfaatkan sumber, metode, penyidik dan teori. Wawancara menjadi data penghubung untuk memperjelas data-data atau catatan-catatan hasil pengamatan serta memperdalam pemahaman yang diperoleh. Studi dokumen menjadi data tambahan untuk mengetahui perencanaan dan hasil evaluasi dari penyelenggara layanan pendidikan homenschooling.

Dalam mempersiapkan riset protokol terkandung hal-hal yang berkaitan dengan nilai-nilai peneliti, harapan dan perspektif yang tercermin di dalamanya sehigga dengan riset protokol ini memudahkan penelitimemiliki panduan dalam menggali informasi kedepannya. Istilah protokol sendiri diguanakan untuk menyiratkan satu set prosedur pertanyaan yang luas dari instrument klasik. Riset protokol bukanlah instrument, yakni pertanyaanpertanyaan terstruktur dengan baik, dengan pertanyaan tertutup dan terbuka dalam item survey penelitian atau numerik angka-angka dan prosedur dalam percobaan manusia. Namun sebaiknya, sebuah protokol riset merupakan protoKol yang sangat terstruktur yang hanya terdiri atas satu set dari topik yang akan dikaji/ diteliti. Dalam hal ini adalah fokus dan sub fokusnya. Karena penelitian studi kasus ini merupakaan salah satu dari strategi penelitian kualitataif, makaa deskriptif pada hasil penelitian ini harus lengkap atau rinci.dalam mendeskripsikan hasil penelitian ini maka peneliti harus memperhatikan pula pertanyaanpertanyaan yang diajukan sebagai riset protokolnya.

\section{G. Prosedur Analisis Data}

Dalam penelitian ini analisis data dilakukan secara kualitatif. Menurut Denzin dan Lincoln, analisis data kualitataif dapat dilakuakan dengan berbagai cara, termasuk pengalaman pribadi dan penafsiran atas dokumen, hasil wawancara atau apa yang diobservasi.

Asia dan Australia dan dua samudera yakni Samudera Pasifik dan Samudera Hindia, disertai kekayaan melimpah, telah menimbulkan niat bangsa-bangsa asing untuk menguasainya.

Pada abad XVI dan XVII masuklah bangsa-bangsa asing ke Indonesia, seperti Portugis, Spanyol dan Belanda dan merupakan penetrasi Eropa dalam bentuk kekuasaan kolonialisme, sehingga Indonesia pun menjadi negeri yang terjajah. Kedatangan bangsa-bangsa ini 
pada awalnya mereka menyebarkan agama dan ideologi penjajahan kemudian mengembangkan sistem pendidikan. Sebelum Indonesia dijajah oleh bangsa lain, bangsa Indonesia telah memiliki tradisi pendidikan sendiri yang dikelola oleh masyarakat atau komunitas yang dipengaruhi oleh adat istiadat, tradisi, budaya, agama dan kepercayaan masingmasing.

Sebagai gambaran bahwa pendidikan di kalangan masyarakat Sulawesi Utara.

\section{HASIL PENELITIAN}

A. Gambaran Umum Tentang Latar Penelitian

Keluarga berfungsi sebagai agen sosialisasi nilai-nilai terhadap anak. Setiap anak selalu berada dalam pangkuan atau lingkungan keluarganya masingmasing karena keluarga merupakan primary group yang membimbing dan memperkenalkan norma-norma sosial kepada anak.

Hubungan keluarga dengan anak memiliki fungsi internalisasi atau menanamkan aturan-aturan hidup di dalam masyarakat, sehingga dapat dihayati oleh anak. Tugas setiap orang tua untuk membimbing, memperkenalkan kepada anak-anaknya nilai yang ada dalam masyarakat. Berkaitan pula dengan fungsi menempatkan anak dalam masyarakat, upaya tersebut senantiasa menyiapkan anak agar dapat diterapkan dalam pergaulan ditengah masyarakat.

Fungsi lain dari keluarga adalah fungsi sosialisasi atau membimbing setiap anak agar mampu hidup sebagai warga negara yang baik, dengan selalu mengindahkan norma-norma sosial, tugas setiap ayah dan ibu untuk selalu mengawasi, mengontrol anaknya, agar tidak menyimpang atau bahkan melanggar aturan-aturan yang ada dalam hidup bermasyarakat.

Sekolah adalah institusi kedua setelah keluarga besar, sekolah pun memiliki andil terhadap pembentukan dan pengembangan pengetahuan anak. Namun, sekolah formal sebagai tempat berlangsungnya proses pendidikan mempunyai keterbatasan-keterbatasan yang seringkali tidak dapat memenuhi harapan orang tua maupun kebutuhan anak.

Pendidikan yang dilakukan secara mandiri oleh orangtua dan lingkungan komunitas berdasarkan Undang-Undang Nomor 20 tahun 2003 tentang sistem pendidikan nasional disebut pendidikan jalur informal. Dalam sistem pendidikan nasional, antara jalur pendidikan (formal, informal dan nonformal) dapat saling melengkapi dan memperkaya. Anak-anak dan orangtua berhak memilih dan pindah jalur pendidikan sesuai dengan kebutuhan dan keadaannya masing-masing.

Pendidikan informal melalui sekolah rumah yang didalam penelitian ini disebut sebagai homeschooling, tepatnya penelitian ini dilakukan di Homeschooling Kak Seto. Homeschooling Kak Seto sebagai institusi pendidikan informal berupaya memberikan kesempatan kepada masyarakat untuk memperoleh layanan pendidikan secara fleksibel sesuai dengan kebutuhan, namun hasilnya diakui sama dengan pendidikan formal atau nonformal.

\section{PEMBAHASANTEMUAN PENELITIAN}

A. Subfokus 1

Pembelajaran sejarah yang dilaksanakan dalam program distance learning homeschooling dilaksanakan berdasarkan perspektif bahwa pendidikan adalah 
usaha sadar dan terencana untuk mewujudkan suasana belajar dan proses pembelajaran agar peserta didik secara aktif mengembangkan potensi dirinya untuk memiliki kekuatan spiritual keagamaan, pengendalian diri, kepribadian, kecerdasan, akhlak mulia, serta keterampilan yang diperlukan dirinya, masyarakat, bangsa dan Negara.

\section{B. Subfokus 2.}

Peranan kedua orang tua dan anggota keluarga bagi anak homeschooling yang memilih program distance learning sebagai program pembelajaranya amatlkah penting. Seorang anak homeschooling menjadikan rumah sebagai ruang belajarnya, tidak hanya sebagai ruang belajar namun tempat mengembangkan kreatifitas. Aktifitas yang dominan dirumah dengan interaksi yang intens dengan anggota keluarga membuat anak merasa dilindungi, diperhatikan oleh keluarga.

\section{Subfokus 3}

Keluarga yang memilih distance learning sebagai program pembelajaranya meyakini bahwa program tersebut akan bisa mengakomodir kebutuhan anaknya. Biasaya keputusan untuk menentukan pemilihan program ini berawal dari keinginan anak atau keinginan orangtua, banyak hal yang menjadi alasan untuk orangtua dan anak menentukan keputusan pemilihan program.

\section{SIMPULAN DAN REKOMENDASI}

\section{A. Simpulan}

Anak-anak yang mengikuti distance learning melalukan pembelajaran sejarah kebanyakan dengan tidak menggunakan tutor/guru. Anak-anak menyelesaikan tugas dan latihan yang diberikan oleh pihak penyelanggara managemen homeschooling kak seto menyelesaikan dengan bantuan web dari internet.

Peranan orangtua dan tutor sesungguhnya sangatlah penting untuk mengawal pembelajaran sejarah anak dirumah. Seorang anak cenderung untuk tidak bertanggung jawab terhadap tugas belajar mereka jika tidak diarahkan oleh orang tua dan tutornya.

Anak-anak homeschooling yang memilih distance learning sebagai program pembelajaran sejarahnya tentunya mempunyai berbagai alasan yang berbeda. Keluarga homeschooling mempunyai harapan besar agar dengan mengikuti program pembelajaran distance learning pembelajaran sejarah anaknya dapat terakomodir dengan baik. banyak alasan dari mereka mengapa meilih distance learning sebagai program pembelajaran sejarah, alasanya seperti Alasanya antara lain seperti, seorang anak cenderung berasa lebih nyaman jika dia belajar dirumah sendiri, seorang anak merasa trauma dengan pembelajaran model formal disekolah sebelumnya, seorang

\section{B. Rekomendasi}

Berdasarkan hasil kesimpulan dari penelitian ini, dapat diuangkapkan beberapa hal yang dapat disarankan oleh penelitian kepada pihak:

1. Dinas pendidikan nonformal dan informal tingkat kota Tangerang Selatan, sebaiknya melakukan pengawasan dan pertimbangan terhadap para komunitas homeschooling di kota Tangerang Selatan dalam implementasi pembelajaran sejarah yang dalam lapangan dapat terjadi perbedaan antara perencanaan dengan pelaksanaan, karena karakter siswa homeschooling yang beragam. 
2. Lembaga komunitas homeschooling di kota Tangerang Selatan, baik pelaksana maupun tutor diharapkan dapat menerapkan implementasi pembelajaran sejarah dengan baiak sesuai dengan kurikulum yang didesain.

3. Peneliti berikutnya, diharapkan dapat mengembangkan penbelitian ini lebih lengkap dengan menambahkan variabelvariabel yang belum ada. Sehingga dapat semakin memperkaya pengetahuan

4. Mengenai kompetensi siswa khususnya pada komunitas homeschooling.

\subsection{Rekomendasi}

Beberapa hal yang direkomendasikan untuk dapat dilakukan oleh beberapa pihak-pihak terkait yang berkontribusi atas tercapainya kompetensi siswa antara lain:

1. Dinas pendidikan nonformal dan Informal tingkat kota Tangerang Selatan perlu melakukan pertemuan rutin dengan para komunitas homeschooling dan Asah Pena kota Tanbggerang Selatan untuk melakukan kerja sama baik dalam hal pengembangan maupun pengevaluasian implementasi KTSP pada masing-masing komunitas homeschooling dan Asah Pena, selain itu, dinas pendidikan sebaiknya menyelenggarakan seminar atau pelatihan secara berkala kepada para tutor agar dapat meningkatkan kompetensinya dalam mengajar. Sehingga para tutor dapat menciptakan proses pembelajaran sejarah yang semestinya.

2. Lembaga komunitas homeschooling di Kota Tanggerang selatan perlu menerapkan pembelajaran sejarah pada anak homeschooling dengan pendampingan tutor, dan tidak hanya mengandalkan bantuan internet untuk memecahkan tugas belajar anak.

3. Lembaga komunitas Homeschooling kak seto.

4. Lembaga Homeschooling

\section{DAFTAR PUSTAKA}

Abdulloh, Taufiq. “Di Sekitar Pengajaran Sejarah yang Reflektif dan Inspiratif", Sejarah No. 6 Februari. Jakarta: Gramedia., 1996), h. 7.

Abraham H. Maslow, Seri Managemen No. 104 B Motivasi dan Keperibadian: Teori Motivasi dengan Pendekatan Hierarkis Kebutuhan Manusia. Jakarta: PT Midas Surya Grafindo, 2000.

Abazir, Peluang Pemberian Pemikiran Kritis melalui Pengajaran Sejarah, Makalah (Padang: IKIP Padang, 1955).

A. Abe Saputra, Rumahku Sekolahku Jakarta: Graha Pustaka, 2007

Agustyawati dan Solicha. Psikologi Pendidikan Anak Berkebutuhan Khusus. Jakarta: Lembaga Penelitian UIN, 2009.

Alfian, Ibrahim. Sejarah dan Permasalahan Masa Kini, Pidato pengukuhan jabatan guru besar pada Fakultas Sastra Universitas Gajah Mada (Yogyakarta: 12 Agustus 1985).

Arikunto, Suharsimi. Manajemen Penelitian. Jakarta: Rineka Cipta, 1995. Prosedur Penelitian Suatu Pendekatan Praktik. Jakarta: Rienika Cipta, 2006.

Aini, Hassan, "Pengajaran dan Pembelajaran Sejarah di Sekolah: Guru Sebagai Broker Ilmu Sejarah" Dalam Jurnal Masalah Pendidikan. Jilid 21.

Alfian. Magdalia, "Pendidikan Sejarah dan Permasalahan yang dihadapi". Makalah disajikan dalam Seminar Nasional Ikatan Himpunan Mahasiswa Sejarah se-Indonesia (IKAHIMSI), Semarang 16 April 2007. 
Ankersmit, F. R. Refleksi Tentang Sejarah Pendapan-Pendapat Modern tentang Filsafat Sejarah (Jakarta: PT Gramedia 2002), h. 374-375.

Asmani, Jamal Ma'mur. Buku Pintar Home Schooling: Menjadikan Kegiatan Belajar Lebih Nyaman dan Mengena. Jakarta: Flasbook. 2012.

Black, James A \& Champion, Dean J, Metode dan Masalah Peneleitian Sosial, Penerjemah E. Koswara, Dira Sala, dan Alfin Ruzhendi, Bandung: PT Eresco, 1992.

Gazalba, Sigi. Pengantar Ilmu Sejarah Edisi Revisi (Jakarta: Bhatara, 2002).

Hasan, Hamid. Pendidikan Sejarah Indonesia"Isu dalam Ide dan Pembelajaran" (Bandung: Rizki Press, 2012).

Heri Purwanto, Modul Pembelajaran; Pendidikan Anak Berkebutuhan Khusus: UPI Bandung.

"Homeschooling, Pendidikan Alternatif Masa Depan", Dr. Seto Mulyadi, Makalah Seminar, 2006.

Kartodirdjo, Sartono. Pendekatan Ilmu Sosial Dalam Metodologi Sejarah, (Jakarta: PT Gramedia Pustaka, 2002).

Kartodirdjo, Sartono. Sejarah Nasional dan Pembangunan Bangsa, Pendekatan Ilmu Sosial dalam Metodologi Sejarah (Jakarta: PT. Gramedia Pustaka Utama, 2002).

Kuntowijoyo. Pengantar Ilmu Sejarah, (Yogyakarta: Bentang Bhudaya 2009).

Kochhar, S.K. Pembelajaran Sejarah, Terjemahan Purwanta dan Yovita Hardiati. (Jakarta: PT Grasindo, 2008).

Kompas Cyber Media, 29 Agustus 2005: "Homeschooling" Model Pendidikan Alternatif"

Miles, Matthew B. Analisis Data Kualitatif, Jakarta: UI Press, 2003

Muhamad Rohman. Kurikulum Berkarakter, Jakarta: Prestasi Pustaka, 2012

Muhibbin Syah, Psikologi Pendidikan dengan Pendekatan Baru, Bandung: PT Rosdakarya, 2008.
Mulyadi Seto, Homeschooling Keluarga Kak Seto (Bandung: Kaifa, 2007).

Moleong, Lexy J. Metodologi Penelitian Kualitatif Edisi Revisi, Bandung: PTRemaja Rosdakarya, 2005.

M. Ngalim Purwanto. Psikologi Pendidikan, Bandung: PT Rosdakarya, 2002.

Mulyadi. Seto, Homeschooling Keluarga Kak Seto, Bandung: Mirza Media U t a $\mathrm{m}$ a, Jakarta. penerbit Kaifah, 2004

Saerie Febriane/Clara Wresti, Rumah Kelasku Dunia Sekolahku, Harian Kompas, 13

Notosusanto, Nugroho.Unsur-Unsur Dasar Penelitian dan Penulisan Sejarah Seri Teks Book Sejarah Abri, (Jakarta: Hankam Pusjarah ABRI, 1971).

Hadi, Sitrisno, Methodologi Research 2 (Yogyakarta: Yayasan Penerbitan Fakultas Psikologi Universitas Gadjah Mada, 2002.

Jamaris, Martini. Orientasi Baru dalam Psikologi Pendidikan (Jakarta: Gramedia, 2011), h. 261.

Sardiman, Pembelajaran Sejarah dan Pembentukan Masyarakat Madani,(Forum Pendidikan, Vol. 02, 2006.

Seels Barbara B. dan Rita C. Richey.Teknologi Pembelajaran Definisi dan Kawasannya. Terjemahan Dewi S Prawirasilaga dan YusufhadiMiarso, Jakarta: Unit Penerbitan UNJ, 2001.

Setijadi, Pendidikan Jarak Jauh, Jakarta: Universitas Terbuka, 1999.

Sugiyono. Metode Penelitian Pendidikan (Pendekatan Kuantitatif, Kualitatif dan RED). Bandung: Alfabeta, 2008.

Sumanto, Psikolofgi Perkembangan Fungsi dan Teori, Jakarta: CAPS, 2002

Sumardiono, Warna-Warni Homeschooling Jakarta: Gramedia, 2007.

Sumardiono, Apa Itu Homeschooling, Jakarta: Gramedia, 2007.

Sumadi Suryabrata, Metodologi Penelitian, Jakarta: PT Rajagrafindo Persada,2005. 
Yin, Robert K., Case Study Research: Design and Methods 2nd ed. California: Sage Publications, 1994.

Yamin, Martinis. Strategi \& Metode dalam Model Pembelajaran. Jakarta: Referensi. 2013.

Yayah Komariah, Homeschooling trend baru sekolah alternative (Jakarta: Sakura, 2007)

Yorgi Gusman, Ikutan Homeschooling, 08 September 2006. 